\title{
The antioxidant properties of calafate (Berberis microphylla) fruits from four different locations in southern Chile
}

\author{
Emilia Mariangel ${ }^{1}$, Marjorie Reyes-Diaz ${ }^{2}$, Walter Lobos ${ }^{1}$, Emma Bensch $^{1}$, \\ Heidi Schalchli ${ }^{3}$, and Pamela Ibarra ${ }^{1}$
}

${ }^{1}$ Facultad de Ciencias Agropecuarias y Forestales, Universidad de La Frontera. Casilla 54-D. Temuco, Chile. ${ }^{2}$ Departamento de Ciencias Químicas y Recursos Naturales, Facultad de Ingeniería, Ciencias y Administración, Universidad de La Frontera. Casilla 54-D. Temuco, Chile.

${ }^{3}$ Centro de Biotecnología Ambiental, Núcleo Científico Tecnológico en Biorecursos (BIOREN), Universidad de La Frontera. Casilla 54-D. Temuco, Chile.

\begin{abstract}
E. Mariangel, M. Reyes-Diaz, W. Lobos, E. Bensch, H. Schalchli, and P. Ibarra. 2013. The antioxidant properties of calafate (Berberis microphylla) fruits from four different locations in southern Chile. Cien. Inv. Agr. 40(1):161-170. The antioxidant capacity (AC), total anthocyanins (TA) and total phenols (TP) of calafate fruit from four locations in southern Chile (El Blanco, Lonquimay, Mañihuales and Temuco) were determined using both the free radical 2.2-diphenyl-1-picrylhydrazyl (DPPH) method and the linoleic acid oxidation inhibition method as well as the pH-differential and Folin-Ciocalteu methods. Phenolic compounds were also identified using HPLC-DAD (High Performance Liquid Chromatography-Diode-Array Detection). The results showed that TP varied significantly according to the location. Mañihuales was noteworthy, with $34.9 \mathrm{mg}$ of GAE g-1 dried fruit. The measured AC level depended on the methodology used, varying significantly between locations according to the DPPH results. Mañihuales was again noteworthy, with the highest $\mathrm{AC}$ values $\left(9.4 \mathrm{mg}\right.$ of TE $\mathrm{g}^{-1}$ dried fruit). The results based on the inhibition of linoleic acid oxidation showed no significant differences between Temuco and El Blanco, and the highest value was found for Mañihuales $(0.25 \mathrm{mg}$ of TE $\mathrm{g}^{-1}$ dried fruit). The TA showed significant differences among locations and was highest for El Blanco ( $0.64 \mathrm{mg}$ of cyanidin $\mathrm{g}^{-1}$ dried fruit). The phenolic acid compounds that were identified included gallic acid, chlorogenic acid, caffeic acid, coumaric acid, ferulic acid and flavonoids such as rutin, myricetin, quercetin and kaempferol. These compounds varied according to location. Temuco showed a higher content of coumaric acid; Lonquimay of chlorogenic acid, caffeic acid, coumaric acid and flavonoids such as rutin and quercetin; Mañihuales of gallic acid, chlorogenic acid, caffeic acid, ferulic acid and flavonoids such as rutin and quercetin; and El Blanco of caffeic acid and flavonoids such as myricetin, quercetin and kaempferol. The $\mathrm{AC}$ was positively correlated with $\mathrm{TP}$ (DPPH $\mathrm{r}=1$, linoleic acid $\mathrm{r}=0.84$ ). In contrast, a low correlation was obtained between AC and TA (DPPH r $=0.31$; linoleic acid $\mathrm{r}=-0.28$ ) and between TP and AT ( $r=0.27)$. It is concluded that calafate fruits from different geographical areas of southern Chile show statistically significant differences in antioxidant capacity, total phenols, anthocyanins and phenolic compounds, with Mañihuales showing the highest values for these parameters. The chemical composition of the fruits also varies with the origin of the samples.
\end{abstract}

Key words: Antioxidants, antioxidant capacity, Berberis, flavonoids, phenolic acids, total phenols.

Received March, 19. Accepted October 4, 2012.

Corresponding author: pibarra@ufro.cl 


\section{Introduction}

Chile is recognized as a fruit exporter. Its fruit exports are principally based on introduced species such as grapes, apples, raspberries and blueberries. Likewise, Chile is considered the largest exporter of blueberries worldwide and the second largest exporter of raspberries in the Southern Hemisphere. However, few species of berries are adapted to grow in the soil and climatic conditions of Chile. Because of this difficulty, efforts have been made to introduce new plant varieties optimally adapted to enhance berry quality and production. Nevertheless, Chilean native species have been investigated as a diversification alternative, including murta (Ugni molinae Turcz.) and maqui (Aristotelia chilensis (Mol.) Stuntz). Another species, less often investigated in terms of genetic variability, crop feasibility and the benefits resulting from its use, is the calafate (Berberis microphylla G. Forst). Calafate belongs to the family Berberidaceae; it is a shrub whose fruit is an edible bluish-black berry. The production of its fruit as a wild crop is concentrated in small gardens in the Regions of Aysén and Magallanes for use in jams and juices. Currently, there are few scientific publications that address the chemical characteristics of the fruit. However, Ruiz et al. (2010) note the interesting finding that native berries have a high polyphenol content and antioxidant capacity. According to Hoffmann (1991), the calafate in Chile is distributed from Curicó to Tierra del Fuego and occurs at different altitudes. Thus, the calafate can potentially be produced in a great variety of areas, but no previous studies have related the antioxidant capacity of the fruits to the location of the crop. The chemical characteristics of calafate fruits and other native fruits may vary depending on weather conditions and plant location, and this variation affects the antioxidant capacity of the fruits (Ruiz et al., 2010). In this context, we hypothesize that the antioxidant properties of calafate fruits vary geographically. The main objective of this study was to evaluate and compare the antioxidant capacity and the content of phenolic compounds of calafate fruits from different geographical areas in southern Chile.

\section{Materials and methods}

This study was conducted in the Plant Tissue Culture Laboratory, Facultad de Ciencias Agronómicas y Forestales, Universidad de La Frontera, Temuco, Chile. The plant material consisted of wild calafate fruit collected between December 2009 and February 2010 from four locations in Chile. Temuco (Time 18. UTM coordinates 5698408 South, 699751 East) and Lonquimay (Time 19. UTM coordinates 5739635 South, 294256 East) are in the La Araucanía Region. Mañihuales (Time 19. UTM coordinates 4580967 South West 7197553) and El Blanco (Time 19. UTM coordinates 4581011 South West 7197522) are in the Aysén del General Carlos Ibáñez del Campo Region. The fruit was collected when at least $50 \%$ of the berries on the plant had reached a state of apparent ripeness according to background color. The fruit was placed in plastic containers with an ice pack and immediately transported to the laboratory, where it was maintained at $-18^{\circ} \mathrm{C}$ until use.

Primarily, the fruit was analyzed in terms of soluble solids (\%) with a calibrated refractometer with distilled water. The moisture content of the fruit was then determined by drying to constant weight according to AOAC (1990). For this purpose, $1 \mathrm{~g}$ of fresh fruit samples was placed in aluminum capsules and maintained in an oven at $105{ }^{\circ} \mathrm{C}$ until reaching constant weight. The samples were cooled and weighed, and the percentage of moisture was calculated from the difference in weight according to the following equation:

$$
\mathrm{H}_{\mathrm{bs}}=\frac{\mathrm{m}_{\mathrm{H}}-\mathrm{m}_{\mathrm{s}}}{\mathrm{m}_{\mathrm{s}}}
$$

where Hbs: solid moisture measured in units of weight of water per unit weight of dry solids (Perry, 1992), $\mathrm{m}_{\mathrm{H}}$ : wet mass and $\mathrm{m}_{\mathrm{S}}$ : dry mass. 
The extracts for the analysis of total phenols (TP), total anthocyanins (TA) and antioxidant capacity (AC) were prepared as follows: $5 \mathrm{~g}$ of dry fruit was macerated in a mortar for 5 min with $25 \mathrm{~mL}$ of water / ethanol 1: $1(\mathrm{v} / \mathrm{v})$. This material was vacuum filtered and separated from the solid material with $\mathrm{N}^{\circ} 1$ Whatman filter paper. After filtration, the extracts were concentrated in a rotary evaporator and stored at $-18{ }^{\circ} \mathrm{C}$ until use (Shene et al., 2009). For the HPLC analysis, samples of fresh fruit were weighed and then macerated with a mortar. A quantity of $1 \%$ acidified methanol was added to obtain a homogeneous mixture. The mixture was then centrifuged at 13,000 rpm for $5 \mathrm{~min}$. The supernatants were obtained and stored at $-80^{\circ} \mathrm{C}$ until use.

Determination of total phenols. Total phenols (TP) were analyzed by Folin-Ciocalteu's colorimetric method (Singleton and Rossi, 1965). Asami et al. (2003) and Zheng and Wang (2003) used this methodology to study phenols in berries. For the analyses, a dilution of each sample was added to each test tube: $0.2 \mathrm{~mL}$ of sample, $1 \mathrm{~mL}$ of FolinCiocalteu and $0.8 \mathrm{~mL}$ of $\mathrm{NaCO}_{3}$. The samples were analyzed in duplicate. The absorbance was measured at $765 \mathrm{~nm}$ after $15 \mathrm{~min}$ of rest at $45^{\circ} \mathrm{C}$ in dry bath glass cells. Gallic acid concentration versus absorbance was plotted. The content of phenolic compounds was expressed as gallic acid equivalents according to the following equation:

$$
C=\frac{(m A+n) \times D F \times V}{g \times 1000},
$$

where $\mathrm{C}=$ concentration of gallic acid equivalent (mg gallic acid equivalent $\mathrm{g}^{-1}$ of dry sample) $\mathrm{m}$ : slope of the calibration curve of gallic acid A: absorbance $\mathrm{n}$ : intersection with the axis DF: dilution factor of the sample $\mathrm{V}$ : volume expressed $(\mathrm{mL})$ $\mathrm{g}$ : grams of dry sample used.

Antioxidant capacity by DPPH method. To determine the free radical scavenging, the stable radical 2.2-diphenyl-1-picrylhydrazyl (DPPH) test was used (Von Gadow et al., 1997). To analyze the samples, the following was prepared for each dilution and added to each test tube: $2.2 \mathrm{~mL}$ of ethanol, $1 \mathrm{~mL}$ of sample and $0.8 \mathrm{~mL}$ of DPPH. The sample was stirred and allowed to stand for $30 \mathrm{~min}$ in darkness. The measurements were made in duplicate, and absorbance was measured in a spectrophotometer at $520 \mathrm{~nm}$. The curve was constructed with the Trolox standard. From this curve, the antiradical activity of the samples was calculated in terms of $\mathrm{mg}$ of Trolox equivalent per $g$ of dry sample. The previous equation was used to calculate this parameter by changing the standard and the slope.

Antioxidant capacity by the method of linoleic acid oxidation inhibition. The activities obtained were compared to Trolox as the standard. The following reagents were prepared: a) buffer, $10 \mathrm{mM}, \mathrm{pH}$ 7.4. Two solutions were required to prepare this buffer: (1) sodium di-2 hydrated hydrogen phosphate $\left(\mathrm{NaH}_{2} \mathrm{PO}_{4} 2 \mathrm{H}_{2} \mathrm{O}\right), 3.61 \mathrm{~g}$ dissolved in $100 \mathrm{~mL}$ of deionized water; and (2) Di-sodium hydrogen phosphate 12 hydrate $\left(\mathrm{Na}_{2} \mathrm{HPO}_{4} 12 \mathrm{H}_{2} \mathrm{O}\right), 7.17 \mathrm{~g}$ dissolved in $100 \mathrm{~mL}$ of deionized water. The two solutions were used to obtain the working solution. A total of $19 \mathrm{~mL}$ of (1) was mixed with $81 \mathrm{~mL}$ of (2), mixed with $100 \mathrm{ml}$ of deionized water and decanted into a $200 \mathrm{~mL}$ flask. To obtain a $10 \mathrm{mM}$ solution, $25 \mathrm{~mL}$ of working solution was taken and diluted to the required total volume with deionized water in a $250 \mathrm{~mL}$ flask. b) Sodium dodecyl sulfate solution (SDS). A total of 2.89 $\mathrm{g}$ of SDS was dissolved in $100 \mathrm{~mL}$ of working solution. c) After the addition of the SDS solution, $70 \mu \mathrm{L}$ of linoleic acid was added (Reagent Mix). d) Reagent 2.2-azobis (2-methylpropionamidine) dihydrochloride (AAPH). A total of $0.2 \mathrm{~g}$ of AAPH was dissolved in $10 \mathrm{~mL}$ of deionized water. e) Trolox. A total of $2.5 \mathrm{mg}$ of Trolox was dissolved in $8 \mathrm{~mL}$ of ethanol and $2 \mathrm{~mL}$ deionized water. The solution was then diluted 10 times. The antioxidant activity relative to the formation of conjugated dienes expressed in $\mathrm{mg}$ of equivalent Trolox $\mathrm{g}^{-1}$ dry sample is given by the following equation: 


$$
C=\frac{\left(m^{*} A+b\right) \times 1 \times 10^{6}}{P \times B},
$$

where C: $\mathrm{mg}$ of Trolox equivalent $\mathrm{g}^{-1}$ of dry sample $\mathrm{m}$ : slope of the line in the calibration curve A: absorbance value obtained in the extract samples b: intercept of the line with the axis P: concentration of extract tested B: g initial dry sample $\mathrm{g}^{-1}$ lyophilized sample.

Determination of total anthocyanins. Total anthocyanins (TA) were measured by the $\mathrm{pH}$ differential method described by Cheng and Breen (1991) based on the difference between measurements at $\mathrm{pH} 1.0$ and $\mathrm{pH} 4.5$. The absorbance of the different samples for each $\mathrm{pH}$ value was measured in a spectrophotometer at 510 and 700 $\mathrm{nm}$ and the result calculated as follows:

$$
A=\left[\left(A_{510}-A_{700}\right)_{p H=1.0}-\left(A_{510}-A_{700}\right)_{p H=4.5}\right]
$$

where A: the absorbance difference

A510: absorbance read at $510 \mathrm{~nm}$

A700: absorbance read at $700 \mathrm{~nm}$.

The data were obtained with the extinction coefficient for cyanidin-3 glucoside $(29,600)$ and expressed as $\mathrm{mg} \mathrm{g}^{-1}$ cyanidin dry weight (DW).

Identification of phenolic compounds using HPLC-DAD. The analysis of phenolic compounds in calafate extracts was performed with HPLC (high performance liquid chromatography) using a Jasco (LC-Net II/ADC, Japan) apparatus with a Kromasil reversed phase (RP) 18-column ( $250 \times 4.6 \mathrm{~mm}$ diameter) device equipped with a photodiode array detector (DAD) (Jasco MD 2015 Plus, Tokyo, Japan). The HPLC analysis of phenolic acids and flavonoids was performed as described by Ruhland and Day (2000) with

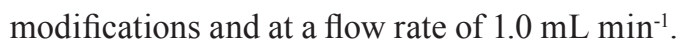
The phenolic acids - chlorogenic, caffeic, ferulic, gallic and p-coumaric and the flavonoids quercetin, myricetin, kaempferol and rutin - were used as standards (Sigma Chemical Co. St. Louis, MO).
These standards were dissolved in methanol for the preparation of calibration curves. The signals were detected at $314 \mathrm{~nm}$. Acidified water (10\% phosphoric acid) (A) and 100\% acetonitrile (B) were used for the mobile phase.

Statistical analysis. The data obtained were analyzed based on a randomized design. For the analysis of total phenols, antioxidant capacity (DPPH), antioxidant (linoleic acid) and anthocyanins, two replicates were considered. To evaluate and determine phenolic compounds, four replicates were considered. The data were analyzed with an ANOVA. The means were compared using a Tukey multiple range test with a significance level of $\mathrm{P} \leq 0.05$. To correlate the antioxidant capacity obtained by the DPPH method as well as by the method of linoleic acid, total anthocyanins, total phenols and percentage of soluble solids, a step-bystep correlation analysis was used. JMP software version 8 was used for the analysis.

\section{Results and discussion}

The total phenol (TP) values ranged from 16.1 to $34.9 \mathrm{mg} \mathrm{GAE} \mathrm{g}^{-1}$ dry fruit, showing statistically significant differences between locations. The highest value was found for Mañihuales (Table 1). This variation could reflect the influence of each location. Studies have shown that the synthesis of phenols is favored by stress conditions in adverse climates (Kong et al., 2003), as in the case of Patagonia. Ruiz et al. (2010) indicated that calafate fruits evaluated in different parts of southern Chile differed significantly. Studies of blueberry and strawberry have reported strong variations in the total phenolic content harvested in different locations and have attributed this variation to the influence of the growth region (Hakkinen et al., 1999; Guerrero et al., 2010).

The AC was determined with two methods, and these methods yielded different results. These differences indicated that the method used strongly 
Table 1. Determination of total phenols, antioxidant capacity (DPPH methods and ability to inhibit the oxidation of linoleic acid), anthocyanins, total soluble solids $\left({ }^{\circ}\right.$ Brix $)$ and moisture (\%) in calafate fruit extracts.

\begin{tabular}{|c|c|c|c|c|c|c|c|c|}
\hline & Temuco & & Lonquimay & & Mañihuales & & El Blanco & \\
\hline Total phenols mg GAE g-1 DW (Folin C.) & $22.2 \pm 0.08$ & $\mathrm{c}$ & $16.1 \pm 0.38$ & d & $34.9 \pm 0.05$ & a & $28.3 \pm 0.36$ & $\mathrm{~b}$ \\
\hline Antioxidant capacity mg TE $\mathrm{g}^{-1} \mathrm{DW}(\mathrm{DPPH})$ & $5.2 \pm 0.02$ & $\mathrm{c}$ & $3.3 \pm 0.01$ & d & $9.4 \pm 0.05$ & a & $7.5 \pm 0.05$ & $\mathrm{~b}$ \\
\hline 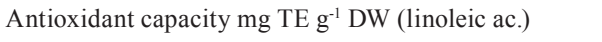 & $0.06 \pm 0.00$ & $\mathrm{~b}$ & $0.04 \pm 0.01$ & $\mathrm{c}$ & $0.24 \pm 0.00$ & a & $0.06 \pm 0.00$ & $\mathrm{~b}$ \\
\hline Total anthocyanins mg cyaniding $\mathrm{g}^{-1} \mathrm{DW}$ ( $\mathrm{pH}$ differential) & $0.24 \pm 0.00$ & $\mathrm{~b}$ & $0.06 \pm 0.00$ & d & $0.12 \pm 0.00$ & $\mathrm{c}$ & $0.64 \pm 0.00$ & $\mathrm{a}$ \\
\hline$\%$ Soluble solids $\left({ }^{\circ} \mathrm{Brix}\right)$ & $11.5 \pm 0.18$ & $\mathrm{~b}$ & $9.3 \pm 2.14$ & $\mathrm{~b}$ & $14.7 \pm 0.33$ & $\mathrm{ab}$ & $22.9 \pm 3.48$ & a \\
\hline $\mathrm{H}^{\circ}(\%)$ & $74.7 \pm 0.06$ & $\mathrm{a}$ & $66.4 \pm 0.98$ & $\mathrm{~b}$ & $63.0 \pm 0.50$ & $\mathrm{c}$ & $64.5 \pm 0.17$ & $\mathrm{bc}$ \\
\hline
\end{tabular}

Different letters in rows indicate significant differences between treatments according to the comparison of means using a Tukey multiple range test $(\mathrm{P} \leq 0.05)$.

influenced the results. The DPPH method showed statistically significant differences between locations, ranging from 3.3 to $9.4 \mathrm{mg} \mathrm{TE} \mathrm{g}^{-1}$ dry fruit. Mañihuales had the highest $\mathrm{AC}$ value $(9.4$ mg TE $\mathrm{g}^{-1}$ dry fruit). The evaluation of the AC by the linoleic acid oxidation inhibition method also indicated that Mañihuales showed the highest value ( $0.25 \mathrm{mg} \mathrm{TE} \mathrm{g}^{-1}$ dry fruit), but the values for El Blanco and Temuco did not differ significantly $\left(0.06 \pm 0.004 ; 0.06 \pm 0.009 \mathrm{mg} \mathrm{TE} \mathrm{g}^{-1}\right.$ dry fruit, respectively). It is possible to infer that commercial farms could produce this nutritionally high-quality fruit in an extensive area of southern Chile (Table 1). In addition, it is known that factors such as pre-harvest environmental conditions, post-harvest processing, genetic differences among species or within the same species and ripeness at harvest may have an impact on fruit antioxidant activity and composition (Kalt et al., 2001; Connor et al., 2002; Castrejón et al. 2008).

The TA values showed statistically significant differences between locations. Fruits from El Blanco showed the highest value, approximately $0.64 \mathrm{mg}$ cyanidin $\mathrm{g}^{-1} \mathrm{DW}$ (Table 1). Similar results were obtained by Ruiz et al. (2010) in a study that assessed the TA concentrations in fresh calafate in four different locations and found the highest concentrations in fruit from Coyhaique. In another study, Peña et al. (2006) assessed the effect of location on the content of TA and $\mathrm{AC}$ in raspberries and concluded that the location (i.e., the city) influenced these values. The literature indicates that this response could be due to factors such as radiation. The functions of the phenolic compounds may include radiation protection. Specifically, TA could protect against light stress. It has been proposed that the TA act as screens and prevent genetic damage in plant cells (O'Neill and Gould, 2003). Strid et al. (1994) concluded that in parsley (Petroselinum sativum), UV radiation affects the genes that encode the synthesis of flavonoids (chalcone synthase and PAL), which, in turn, are key enzymes in the formation of TA. Another factor may be temperature: Guerrero (2006) showed that the $\mathrm{AC}, \mathrm{TA}$ and $\mathrm{TP}$ content of blueberries was significantly higher in fruit from Collipulli than in fruit obtained from locations further south (IX and X Regions of Chile) and suggested that this difference could be due to the climatic conditions of the location, such as high pre-harvest temperatures that would cause a greater growth rate and greater color development in blueberries, resulting in a significant content of antioxidants.

Another important determinant of TA content is the stage of ripeness at harvest. In particular, the total phenolic content decreases when the fruit reaches maturity, whereas the TA content increases substantially (Kalt et al. 2003). TA was found to match the highest content of soluble solids. This result suggests greater fruit ripeness, but this trend did not occur at other locations. Prior et al. (1998) indicated that differences in the degree of ripeness affect the phenolic content, which (with the exception of TA) is usually higher in young fruits than in overripe fruits. The TA content usually accumulates during maturity and depends 
on the temperature and location where the fruits are planted. Ribera et al. (2010) found significant variations in anthocyanidin concentrations and compositions among blueberry cultivars and during their fruit maturation process and found that anthocyanidins were undetectable at greener maturity stages.

We identified the flavonoids rutin, myricetin, quercetin, kaempferol and the following phenolic acids: gallic, chlorogenic, caffeic, coumaric and ferulic. Similar results were found by Ruiz et al. (2010), who found myricetin and quercetin, among others, in calafate fruits. Furthermore, the authors noted that the flavonoid content $\left(0.16 \mathrm{mmol} \mathrm{g}^{-1}\right)$ is comparable to that obtained for maqui ( 0.12 $\mathrm{mmol} \mathrm{g}{ }^{-1}$ ). Other authors found similar results for these species for compounds such as ferulic, coumaric and gallic acids and the flavonoids myricetin, quercetin and rutin (Céspedes et al., 2010). These data suggest that the nutritional quality of calafate is equivalent to that of maqui. In the Portal Antioxidantes database (www. portalantioxidantes.com; accessed February 25, 2012), the ORAC value for maqui is $1413 \mathrm{~mol}$ TE $100 \mathrm{~g}^{-1} \mathrm{FW}$ (average value), and the ORAC value for calafate is $25,662 \mathrm{~mol} \mathrm{TE} 100 \mathrm{~g}^{-1} \mathrm{FW}$ (average value). These values indicate that the antioxidant properties of calafate are excellent. An additional result is that the composition of the calafate varied depending on the place of origin.
The fruit from Mañihuales was high in gallic, chlorogenic, ferulic, gallic and caffeic acid as well as the flavonoids rutin and quercetin. El Blanco showed high caffeic acid, myricetin, kaempferol and quercetin content; Temuco showed high coumaric acid and rutin and quercetin content; and Lonquimay showed high chlorogenic, caffeic and coumaric acid content. These results raise an important issue, as indicated by Pineda et al. (1999), who evaluated the antioxidant capacity of vegetables such as cabbage (Brassica oleracea), lettuce (Lactuca sativa L.), onion (Allium cepa L.) and tomato (Lycopersicon esculentum L.); they found that synergism or antagonism can influence the function of antioxidant compounds. For example, $\alpha$-tocopherol and ascorbic acid, tocopherol and quercetin, rutin and ascorbic acid, caffeic acid and ascorbic acid are highly synergistic, whereas quercetin and ascorbic acid are antagonistic. This information makes it possible to infer that there may be synergism or antagonism among the compounds in calafate because the samples evaluated showed statistically significant differences in terms of antioxidant capacity (Table 2).

A strong correlation $(\mathrm{r}=1)$ was found between $\mathrm{AC}$ and TP. Additionally, a high correlation $(\mathrm{r}=0.84)$ was found between AC (linoleic acid) and TP (Table 3). Ruiz et al. (2010) found a high correlation between AC and TP in calafate. Guerrero (2006)

Table 2. Identification of flavonoids and phenolic acids in fruit extracts of calafate.

\begin{tabular}{|c|c|c|c|c|c|c|c|c|}
\hline \multirow[b]{2}{*}{ Phenolic Compounds } & \multicolumn{8}{|c|}{ Flavonoids and phenolic acids according to the locality $(\mu \mathrm{g} / \mathrm{g} \mathrm{FW} \pm \mathrm{SD})$} \\
\hline & Temuco & & Lonquimay & & Mañihuales & & El Blanco & \\
\hline Gallic acid & $359.9 \pm 38.4$ & $\mathrm{c}$ & $132.3 \pm 15.7$ & d & $1068.0 \pm 71.4$ & a & $776.7 \pm 41.9$ & $\mathrm{~b}$ \\
\hline Chlorogenic acid & $224.0 \pm 14.3$ & $\mathrm{c}$ & $541.8 \pm 19.0$ & $\mathrm{ab}$ & $603.0 \pm 34.1$ & a & $485.2 \pm 35.0$ & b \\
\hline Caffeic acid & $85.9 \pm 4.3$ & $\mathrm{~b}$ & $115.9 \pm 8.5$ & $\mathrm{ab}$ & $120.5 \pm 9.2$ & $\mathrm{ab}$ & $141.1 \pm 10.2$ & $\mathrm{a}$ \\
\hline Coumaric acid & $37.9 \pm 4.8$ & $\mathrm{a}$ & $36.0 \pm 3.9$ & a & $20.0 \pm 1.2$ & $\mathrm{~b}$ & $17.4 \pm 1.4$ & $\mathrm{~b}$ \\
\hline Ferulic acid & $15.3 \pm 1.9$ & $\mathrm{c}$ & $38.6 \pm 2.6$ & b & $75.3 \pm 2.9$ & a & $7.4 \pm 0.6$ & c \\
\hline Rutin & $407.0 \pm 36.2$ & $\mathrm{~b}$ & $578.3 \pm 42.8$ & $\mathrm{a}$ & $460.6 \pm 12.9$ & $a b$ & $400.9 \pm 31.1$ & $\mathrm{~b}$ \\
\hline Myricetin & $12.5 \pm 1.4$ & $\mathrm{~b}$ & $18.9 \pm 0.9$ & $\mathrm{~b}$ & $17.1 \pm 2.0$ & $\mathrm{~b}$ & $42.9 \pm 1.9$ & $\mathrm{a}$ \\
\hline Quercetin & $5.0 \pm 0.5$ & $\mathrm{~b}$ & $8.8 \pm 0.1$ & $\mathrm{a}$ & $8.2 \pm 0.3$ & a & $7.7 \pm 0.8$ & $\mathrm{a}$ \\
\hline Kaempferol & $5.1 \pm 0.4$ & $\mathrm{c}$ & $9.8 \pm 0.7$ & $\mathrm{~b}$ & $11.7 \pm 0.7$ & $\mathrm{~b}$ & $15.5 \pm 1.3$ & $\mathrm{a}$ \\
\hline
\end{tabular}

Different letters in rows indicate significant differences between treatments according to the comparison of means using a Tukey multiple range test $(\mathrm{P} \leq 0.05)$. 
found a high correlation between $\mathrm{AC}$ and $\mathrm{TP}$ in blueberry. A high correlation was also found between TP and AC in cranberry and other fruits (Moyer et al., 2002). A low correlation ( $\mathrm{r}=0.31$ ) was found between $\mathrm{AC}$ and TA, and a low negative correlation $(\mathrm{r}=-0.28)$ was found between $\mathrm{AC}$ measured by linoleic acid and TA (Table 3). This result is important because a higher TA content does not imply a higher AC. However, this result has important implications for the synergism among the phenolic compounds present in the sample. It can therefore be inferred that $\mathrm{AC}$ is more influenced by the set of compounds that interact with each other than by TA alone. In this context, Pineda et al. (1999) noted that synergism or antagonism affects the antioxidant ability of the compounds. By correlating TA with the soluble solids, we found a high correlation, $\mathrm{r}=0.8$. The reason for this high correlation may be that the content of TA, unlike other phenolic compounds, increases with maturation (Prior et al., 1998; Kähkönen et al., 2001). The content of soluble solids also increases as the fruit ripens (Moggia et al., 2005). In turn, a moderate correlation $(\mathrm{r}=0.51)$ was found between TP and soluble solids. This result may be related to a decrease in TP (except for TA) with increasing maturity (Prior et al., 1998, Kähkönen et al., 2001), which in turn increases the soluble solids (Moggia et al., 2005). A low correlation $(\mathrm{r}=0.27)$ was found between TP and TA. The reason for this result could be that the TP decreases as the fruit reaches maturity, whereas the TA content increases substantially (Moyer et al., 2002). Indeed, the same authors found a low correlation $(\mathrm{r}=0.28)$ between TP and TA in currant (Ribes L.).

Based on the evaluation and comparison of the antioxidant capacity and the content of phenolic compounds in calafate from different geographical areas in southern Chile, it is concluded that calafate fruit extracts show statistically significant differences in their antioxidant capacity, total phenols, anthocyanins and phenolic compounds. Mañihuales was the area that showed the highest values for these parameters. The chemical composition of fruit varies depending on the origin of the samples. There is a strong correlation between total phenol and antioxidant capacity and between total anthocyanins and soluble solids.

However, future studies should be performed to determine whether these differences are due to genetic differences and / or the environmental conditions to which the plants are exposed.

\section{Acknowledgments}

The authors wish to thank the Plant Tissue Culture Laboratory, Faculty of Agricultural and Forestry Sciences Laboratory, Bioseparations, Department of Chemical Engineering, and BIOREN-UFRO of the Universidad de La Frontera (Temuco, Chile) for providing the facilities used to perform this research.

Table 3. Correlation analyses for antioxidant capacity, total phenols, total anthocyanins and soluble solids.

\begin{tabular}{|c|c|c|c|c|c|}
\hline & 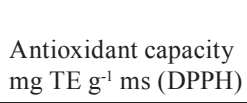 & $\begin{array}{l}\text { Total phenols } \\
\text { mg GAE g-1 } \mathrm{ms} \\
\text { (Folin C.) }\end{array}$ & $\begin{array}{l}\text { Total anthocyanins } \\
\text { mg cyanidin } \mathrm{g}^{-1} \\
\text { (pH- differential) }\end{array}$ & $\begin{array}{l}\text { Antioxidant } \\
\text { capacity mg TE g-1 } \\
\text { ms (linoleic ac.) }\end{array}$ & $\begin{array}{l}\% \text { Soluble } \\
\text { solids ( }{ }^{\circ} \text { Brix) }\end{array}$ \\
\hline $\begin{array}{l}\text { Antioxidant capacity mg } \\
\mathrm{TE} \mathrm{g}^{-1} \mathrm{DW}(\mathrm{DPPH})\end{array}$ & - & 1 & 0.31 & 0.82 & 0.54 \\
\hline $\begin{array}{l}\text { Total phenols mg GAE } \\
\mathrm{g}^{-1} \text { DW (Folin C.) }\end{array}$ & - & - & 0.27 & 0.84 & 0.51 \\
\hline $\begin{array}{l}\text { Total anthocyanins mg } \\
\text { cyaniding } \mathrm{g}^{-1} \mathrm{DW}(\mathrm{pH}- \\
\text { differential) }\end{array}$ & - & - & - & -0.28 & 0.8 \\
\hline $\begin{array}{l}\text { Antioxidant capacity mg } \\
\mathrm{TE} \mathrm{g}^{-1} \mathrm{DW} \text { (linoleic ac.) }\end{array}$ & - & - & - & - & 0.06 \\
\hline$\%$ Soluble solids $\left({ }^{\circ} \mathrm{Brix}\right)$ & - & - & - & - & - \\
\hline
\end{tabular}




\section{Resumen}

E. Mariangel, M. Reyes-Diaz, W. Lobos, E. Bensch, H. Schalchli, y P. Ibarra. 2013. Propiedades antioxidantes de frutos de calafate (Berberis microphylla) evaluadas en cuatro diferentes localidades del sur de Chile. Cien. Inv. Agr. 40(1):161-170. Se determinó la capacidad antioxidante (CA), antocianinas totales (AT) y fenoles totales (FT) de frutos de calafate de cuatro localidades del sur de Chile (El Blanco, Lonquimay, Mañihuales y Temuco) utilizando los métodos del radical libre 2,2-difenil -1- picrilhidrazil (DPPH) y la capacidad de inhibir la oxidación del ácido linoleico, así como pH diferencial y el método de Folin-Ciocalteu. Además, se identificaron los compuestos fenólicos por medio de HPLCDAD (Cromatografía líquida de alta eficacia- con Detección por Arreglo de Diodos). Los resultados mostraron que los FT variaron significativamente según la localidad, destacándose Mañihuales con 34,9 mg GAE g-1 de fruta seca. La CA varió de acuerdo con la metodología, por DPPH varió significativamente entre localidades, y de nuevo se destacó Mañihuales con

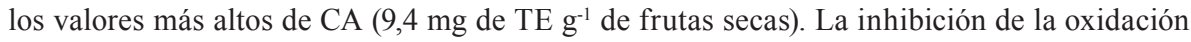
del ácido linoleico reveló que no hubo diferencias significativas entre Temuco y El Blanco, presentando Mañihuales el valor más alto (0,25 $\mathrm{mg} \mathrm{de} \mathrm{TE} \mathrm{g}^{-1}$ de fruta seca). Las AT mostraron diferencias significativas entre localidades, siendo El Blanco el mayor (0,64 mg de cianidina $\mathrm{g}^{-1}$ fruta seca). En relación a los compuestos fenólicos, fueron identificados ácido gálico, ácido clorogénico, ácido cafeico, ácido cumárico, ácido ferúlico, y flavonoides como rutina, miricetina, quercetina y kaempferol. Estos compuestos variaron de acuerdo a la localidad: Temuco mostró un valor más alto de ácido cumárico; Lonquimay en ácido clorogénico, ácido cafeico, ácido cumárico, y flavonoides como rutina y quercetina; Mañihuales en ácido gálico, ácido clorogénico, ácido cafeico, ácido ferúlico y favonoides como la rutina y la quercetina; El Blanco en ácido cafeico y flavonoides como miricetina, quercetina y kaempferol. La CA se correlacionó positivamente con FT (DPPH r=1; ácido linoleico $\mathrm{r}=0,84$ ). Por el contrario, se obtuvo una baja correlación entre la CA y AT (DPPH r=0,31; ácido linoleico $\mathrm{r}=-0,28$ ), y entre FT y AT $(r=0,27)$. Se concluye que los frutos de calafate de diferentes áreas geográficas del sur de Chile tienen diferencias estadísticamente significativas en su CA, FT, AT y compuestos fenólicos, siendo Mañihuales el área que presentó los valores más altos para estos parámetros. La composición química de los frutos también varió dependiendo del origen de las muestras.

Palabras clave: Antioxidantes, capacidad antioxidante, Berberis, flavonoides, ácidos fenólicos y fenoles totales.

\section{References}

AOAC. 1990. Official Methods of Analysis. 15 th edition. Association of Official Analytical Chemists (AOAC). Gaithersburg, Maryland, USA.

Asami, D., Y. Hong, D. Barret, and A. Mitchell. 2003. Comparison of the total phenolic and ascorbic acid content of freeze - dried and air - dried marionberry, strawberry, and corn grown using conventional, organic, and sustainable agricultural practices. Journal of Agricultural and Food Chemistry 51: $1237-1241$.
Castrejón, A.D.R., I. Eichholz, S. Rohn, L.W. Kroh, and S. Huyskens-Keil. 2008. Phenolic profile and antioxidant activity of highbush blueberry (Vaccinium corymbosum L.) during fruit maturation and ripening. Food Chemistry 109:564-572.

Céspedes, C., M. Valdez, J. Avila, M. El-Hafidi, J. Alarcón, and O. Paredes. 2010. Phytochemical profile and the antioxidant activity of Chilean wild black - berry fruits, Aristotelia chilensis (Mol) Stuntz (Elaeocarpaceae). Food Chemistry 119:886-895. 
Cheng, G., and P. Breen. 1991. Activity of phenylalanine ammonia-lyase (PAL) and concentrations of anthocyanins and phenolics in developing strawberry fruit. Journal of the American Society for Horticultural Science 116:865-869.

Connor, A.M., J.J. Luby, BS. Tong, C.E. Finn, and J.F. Hancock. 2002. Genotypic and environmental variation in antioxidant activity, total phenolic content, and anthocyanin content among blueberry cultivars. Journal of the American Society for Horticultural Science 127:89-97.

Guerrero, J. 2006. Capacidad antioxidante, fenoles y antocianinas totales e inhibición de Botrytis cinerea Pers. Ex Fr. Por extractos crudos de fruta de cultivares de arándano alto (Vaccinium corymbosum L.) según localidad de la zona sur de Chile. Tesis Doctoral. Universidad Austral de Chile. Valdivia, Chile. 121 pp.

Guerrero, J., L. Ciampi, A. Castilla, F. Medel, H. Schalchli, E. Hormazabal., E. Bensch, M. Alberdi. 2010. Antioxidant capacity, anthocyanins, and total phenols of wild and cultivated berries in Chile. Chilean Journal of Agricultural Research 70:537-544.

Häkkinen, S., S. Kärenlampi, M. Heinonen, H. Mykkänen, and R. Torrönen. 1999. Content of flavonols quercetin, myricetin, and kaempferol in 25 edile berries. Journal of Agricultural and Food Chemistry 47: 2274-2279.

Hoffman, A. 1991. Flora Silvestre de Chile: Zona Araucana. $2^{\mathrm{a}}$ edición. Editorial Claudio Gay. Santiago, Chile. 246 pp.

Kahkonen, M., A. Hopia, and M. Heinonen, 2001. Berry phenolics and their antioxidant activity. Journal of Agricultural and Food Chemistry 49:4076-4082.

Kalt, W., A. Howell, J. C Duy, C.F. Forney, and J.E. McDonald. 2001. Horticultural factors affecting antioxidant capacity of blueberries and other small fruits. Horttechnology 11:523-528.

Kalt, W., Ch. Lawand, D. Ryan, J. McDonald, H. Donner, and Ch. Forney. 2003. Oxygen radical absorbing capacity, anthocyanin and phenolic content of highbush blueberries (Vaccinium corymbosum L.) during ripening and storage.
Journal of the American Society for Horticultural Science 128:917-923.

Kong, J., L. Chia, N. Goh, T. Chia, and R. Brouillard. 2003. Analysis and biological activities of anthocyanins. Phytochemistry 64:923-933.

Moggia, C., M. Pereira. J. Yuri, and M. Moya. 2005. Evolución de la madurez en pre y post cosecha y potencialidad de almacenaje de peras Packham's Triumph. Agricultura Técnica 65:246-257.

Moyer, R., K. Hummer, Ch. Finn, B. Frei, and R. Wrolstad. 2002. Anthocyanins, phenolics, and antioxidant capacity in diverse small fruits: Vaccinium, Rubus, Ribes. Agricultural and Food Chemistry 50:519-525.

O'Neill, S., and K. Gould. 2003. Anthocyanins in leaves: ligth attenuators or antioxidants? Functional Plant Biology 30: 865 - 873.

Perry, R. 1992. Manual del ingeniero químico. 6a Edición. Editorial McGraw- Hill, México.

Peña, G., Y. Salinas, and R. Ríos, 2006. Contenido de antocianinas totales y actividad antioxidante en frutos de frambuesa (Rubus ideaus L.) con diferente grado de maduración. Revista Chapiro. Serie Horticultura 12:159-163.

Pineda, AD., M. Salucci, R. Lázaro, G. Maiani, and A. Ferro-Luzzi. 1999. Capacidad Antioxidante y potencial de sinergismo entre los principales constituyentes antioxidantes de algunos alimentos. Revista Cubana de Alimentación y Nutrición 13:104-111.

Prior, R., G. Cao, A. Martin, E. Sofic, J. McEwen, C. O'Brien, N. Lischner, M. Ehlenfeldt, W. Kalt, G. Krewer, and C. Mainland. 1998. Antioxidant capacity as influenced by total phenolic and anthocyanin content, maturity, and variety of Vaccinium species. Journal of Agricultural and Food Chemistry 46:2686-2693.

Ribera, A.E., M. Reyes-Diaz, M. Alberdi, G.E. Zuñiga, and M.L. Mora. 2010. Antioxidant compounds in skin and pulp of fruits change among genotypes and maturity stages in highbush blueberry (Vaccinium corymbosum L.) grown in southern Chile. Journal of Soil Science and Plant Nutrition 10:509-536.

Ruhland, C.T., and T.A. Day. 2000. Effects of ultraviolet-B radiation on leaf elongation, 
production and phenylpropanoid concentrations in Deschampsia antarctica and Colobanthus quitensis in Antarctica. Physiologia Plantarum 109:244-251.

Ruiz, A., I. Gutierrez, C. Mardones, C. Vergara, E. Herlitz, M. Vega, C. Dorau, P. Winterhalter, and D. von Baer. 2010. Polyphenols and antioxidant activity of Calafate (Berberis microphylla) fruit and other native berries from southern Chile. Journal of Agricultural and Food Chemistry 58:6081-6089.

Shene, C., A. Reyes, M. Villarroel, J. Sineiro, M. Pinelo, and M. Rubilar. 2009. Plant location and extraction procedure strongly alter the antimicrobial activity of murta extracts. European Food Research and Technology 228:467-475.

Singleton, V., and L. Rossi. 1965. Colorimetry of total phenolics with phosphomolybdic- phosphotungstic acid reagents. American Journal of Enology and Viticulture 16:144-158.

Strid, A., W. Chow, and J. Anderson. 1994. UV- B damage and protection at the molecular level in plants photosynth. Photosynthesis Research 39: 475 - 489.

Von Gadow, A., E. Joubert, and C. Hansmann. 1997. Comparison of the antioxidant activity of aspalathin with that of other plant phenols of rooibos tea (Aspalathus linearis), $\alpha$ - tocophenol, BHT and BHA. Journal of Agricultural and Food Chemistry 45:632-638.

Zheng, W. and S. Wang. 2003. Oxygen radical absorbing capacity of phenolics in blueberries, cranberries, chokeberries, and lingonberries. Journal of Agricultural and Food Chemistry 51:2122-2127. 